\title{
Penggunaan Alat Pelindung Diri pada Perawat Rawat Jalan dan Rawat Inap
}

\author{
Rian Muhammad Kiswara' ${ }^{1}$, Mifbakhuddin $^{1}{ }^{\square}$, Diki Bima Prasetio ${ }^{1,2}$ \\ ${ }^{1}$ Fakultas Kesehatan Masyarakat, Universitas Muhammadiyah Semarang \\ ${ }^{2}$ Laboratorium Keselamatan dan Kesehatan Kerja Universitas Muhammadiyah Semarang
}

\author{
Info Artikel \\ Diterima 12 Agustus 2020 \\ Disetujui 23 September 2020 \\ Diterbitkan 30 November 2020
}

\author{
Kata Kunci: \\ Penggunaan APD, \\ Perawat, \\ Rumah sakit. \\ e-ISSN: \\ 2613-9219
}

Akreditasi Nasional:

Sinta 4

\section{Keywords:}

Hospital,

Nurse,

Use of PPE.

\section{$\square^{\square}$ Coresponding author: mif@unimus.ac.id}

\begin{abstract}
Abstrak
Latar belakang : Rumah sakit adalah suatu intitusi pelayanan kesehatan yang bergerak dalam bidang kesehatan dengan fungsi menyelenggarakan pelayanan kesehatan yang berkaitan dengan pencegahan dan penyembuhan penyakit pada masyarakat. Perawat merupakan seorang yang mempunyai kemampuan khusus untuk memberikan pelayanan kesehatan dan bertanggung jawab dalam pencegahan penyakit baik pasien maupun dirinya sendiri. Metode: Jenis penelitian ini adalah observasional analitik. Penelitian observasional analitik dengan pendekatan cross-sectional. Hasil : Perawat rawat jalan dan rawat inap RSU X memiliki usia lebih dari 35 orang sebanyak 8 orang $(23,5 \%)$ dan kurang dari sama dengan 35 sebanyak 26 orang $(76,5 \%)$. Jenis kelamin yang berjenis kelamin laki-laki sebnyak 2 orang $(5,9 \%)$ dan yang berjenis perempuan sebanyak 32 orang $(94,1 \%)$. Masa kerja $<5$ tahun sebanyak 9 orang $(26,5 \%)$ dan $\geq 5$ tahun sebanyak 25 orang $(73,5 \%)$. Kategori pengetahuan dikatakan baik sebanyak 14 orang $(41,2 \%)$, cukup sebanyak 10 orang $(29,4 \%)$ dan pengetahuan dikatakan kurang baik sebanyak 10 orang $(29,4 \%)$. Kategori pengawasan yang dikatakan baik sebanyak 28 orang $(82,4 \%)$ dan dan pengawasan kurang baik sebanyak 6 orang $(17,6 \%)$. Simpulan : Tidak ada hubungan antara usia, jenis kelamin, masa kerja, pengetahuan, dan pengawasan dengan kepatuhan penggunaan APD pada perawat rawat jalan dan rawat inap di RSU X $p$ value lebih $>0,05$.
\end{abstract}

\begin{abstract}
Background: Hospital is an institution of health services that is engaged in the field of health with the function of organizing health services related to the prevention and cure of diseases in the community. The nurse is a person who has a special ability to provide health services and is responsible for preventing both the patient and himself. Method: This type of research is analytic observational. Analytic observational research with cross-sectional approach. Results: Outpatient and inpatient at X General Hospital had more than 35 people aged 8 people $(23.5 \%)$ and less than the same as 35 as many as 26 people (76.5\%). The sexes of the men are 2 people $(5.9 \%)$ and the types of women are 32 people $(94.1 \%)$. The working period $<5$ years is 9 people $(26.5 \%)$ and $\geq 5$ years is 25 people $(73.5 \%)$. The knowledge category is said to be good as many as 14 people (41.2\%), quite as much as 10 people $(29.4 \%)$ and knowledge is said to be poor as many as 10 people $(29.4 \%)$. The category of supervision is said to be good as many as 28 people $(82.4 \%)$ and and supervision is not good as many as 6 people $(17.6 \%)$. Conclusion: There is no relationship between age, sex, years of service, knowledge, and supervision with compliance with the use of PPE in outpatient and inpatient care at X General Hospital $\mathrm{p}$ value more $>0.05$.
\end{abstract}




\section{Pendahuluan}

Rumah sakit adalah suatu intitusi pelayanan kesehatan yang bergerak dalam bidang kesehatan dengan fungsi menyelenggarakan pelayanan kesehatan yang berkaitan dengan pencegahan dan penyembuhan penyakit pada masyarakat ${ }^{1,2,3}$. Pelayanan kesehatan bertujuan untuk meningkatkan kesehatan pasien dan menjaga kesehatan karyawan agar selalu sehat dan selamat dalam melakukan pekerjaan ${ }^{4}$. Karyawan yang bekerja di fasilitas kesehatan berisiko terpapar penyakit atau infeksi yang dapat berpotensi membahayakan jiwa ${ }^{5}$. Salah satu potensi bahaya di rumah sakit adalah terpapar penyakit yang dapat mengganggu kesehatan kerja, terutama bagi perawat ${ }^{6}$.

Perawat merupakan seorang yang mempunyai kemampuan khusus untuk memberikan pelayanan kesehatan dan bertanggung jawab dalam pencegahan penyakit baik pasien maupun dirinya sendiri ${ }^{7,8}$. Perawat memperoleh paparan penyakit dari berbagai wilayah kerja diantaranya, kamar operasi (46\%), kamar bersalin $(37 \%)$, ruang rawat inap (11\%), ruang nifas (3\%), lainlain $(3 \%)^{9}$. Kemungkinan perawat terinfeksi setelah terpajan dengan pathogen yang bervariasi, diperkirakan dengan rentang dari 30\% untuk hepatitis B (personel layanan kesehatan yang tidak kebal), 1,8\% untuk hepatitis $\mathrm{C}$, hingga $0,3 \%$ untuk $\mathrm{HIV}^{10}$. Penyebab terjadinya kecelakan dan penyakit akibat kerja dengan adanya cidera mulai dari tertusuk jarum hingga tergores karena alat medis yang sebelumnya di gunakan untuk pasien dengan resiko penularan virus pathogen seperti HIV dan Hepatitis B, penyakit akibat ini menjadi masalah serius karena menganancam petugas kesehatan $^{11,12 .}$

RSU X, adalah rumah sakit tipe D yang telah melaksankan sistem K3 rumah sakit pada tahun 2018, dimana dalam menerapkan sistem K3 rumah sakit setiap pekerjaan harus memiliki standart operasional prosedur (SOP) dalam melakukan pekerjaan. Salah SOP dirumah sakit adalah penggunaan APD pada perawat ditempat kerja. Berdasarkan stuidi pendahuluan yang dilakukan di latar pada 8 perawat terdapat 5 orang perawat saat dalam penanganan pasien tidak menggunakan alat pelindung diri seperti masker dan handscun. Dalam triwulan IV atau pada bulan Oktober - Desember 2018 terdapat 2 kejadian kecelakaan kerja satu diantaranya disebabkan oleh kelalaian dalam penggunaan APD sehingga perawat bisa tertusuk jarum dalam melakukan tindakan. Adapun alasan perawat yaitu ingin buru-buru/ cepat, terkadang mengganggu/ tidak aman, risih dan tidak ada sanksi jika tidak menggunakan Alat Pelindung Diri atau tidak ada sanksi yang berupa tertulis dan atau cuma berupa teguran dari kepala ruangan.

\section{Metode}

Jenis penelitian ini adalah observasional analitik. Penelitian observasional analitik adalah penelitian yang digunakan untuk menganalisis hubungan antar variabel $^{13}$. Pendekatan yang digunakan adalah studi cross-sectional. Studi ini melakukan kegiatan observasi dan pengukuran terhadap variabel-variabel pada satu titik waktu tertentu ${ }^{14}$. Populasi dalam penelitian ini adalah perawat rawat jalan (14 orang) yang bekerja 2 sift pagi dan siang dan rawat inap (20 orang) yang bekerja 3 sift (pagi, siang, dan malam), jadi jumlah perawat sebanyak 34 orang di RSU X.

\section{Hasil}

\section{Analisis Univariat}

Penelitian dilakukan pada perawat rawat jalan dan rawat inap RSU $\mathrm{X}$ di peroleh hasil kepatuhan penggunaan APD yang diukur dengan cara observasi langsung ke lapangan berdasarkan checklist penilaian kepatuhan penggunaan APD pada perawat rawat jalan dan rawat inap paling rendah mendapatkan skor sebesar 8 dan paling tinggi sebesar 21, sedangkan rata-rata skor tingkat kepatuhan sebesar 15,09 dan standar deviasi sebesar 3,604 .

Usia pada Perawat yang berusia terendah adalah 25 tahun, usia tertinggi adalah 50 tahun, dan rata-rata usia yang perawat sebesar 32,68 dengan standar deviasi 5,268. Perawat berusa lebih dari 35 tahun sebanyak 8 orang $(23,5 \%)$. Masa kerja pada perawat rawat jalan dan rawat inap RSU X minimal 1 tahun dan maksimal 28 tahun, sedangkan rata-rata masa kerja yaitu 7,5 tahun dan standar deviasi sebesar 5,572 tahun.

Masa kerja kemudian dilakukan pengakategorian menjadi 2 kategori yaitu $\geq 5$ tahun dan $<5$ tahun. Pengawasan terhadap perawat berdasarkan Tabel 4.1 distribusi deskriptif memiliki skor terendah sebesar 15 , skor tertinggi sebesar 30 pernyataan, dan memiliki rata-rata sebesar 22,24 sedangkan standart devisiai sebesar 5,170.

Kepatuhan penggunaan APD kemudian dikategorikan menjadi 2 kategori yaitu patuh dan tidak patuh. Berdasarkan Tabel 1 distribusi frekuensi variabel penelitian diketahui bahwa pekerja yang patuh sebanyak 25 orang $(73,5 \%)$. Jenis kelamin berdasarkan Tabel 4.2, jumalah perawat yang berjenis kelamin laki laki sebanyak 2 orang, dan perawat yang berjenis perempuan sebanyak 32 orang. 
Tabel 1. Ditribusi Frekuentif Variabel Penelitian

\begin{tabular}{|c|c|c|}
\hline Variabel & Frekuensi & $\begin{array}{c}\text { Persentase } \\
(\%)\end{array}$ \\
\hline \multicolumn{3}{|l|}{ Usia } \\
\hline$>35$ Tahun & 8 & 23,5 \\
\hline$\leq 35$ Tahun & 26 & 76,5 \\
\hline Total & 34 & 100,0 \\
\hline \multicolumn{3}{|l|}{$\begin{array}{l}\text { Jenis } \\
\text { Kelamin }\end{array}$} \\
\hline Laki-Laki & 2 & 5,9 \\
\hline Perempuan & 32 & 94,1 \\
\hline Total & 34 & 100,0 \\
\hline \multicolumn{3}{|l|}{ Masa kerja } \\
\hline$<5$ tahun & 9 & 26,5 \\
\hline$\geq 5$ tahun & 25 & 73,5 \\
\hline Total & 34 & 100,0 \\
\hline \multicolumn{3}{|l|}{ Pengetahuan } \\
\hline Kurang & 10 & 29,4 \\
\hline Cukup & 10 & 29,4 \\
\hline Baik & 14 & 41,2 \\
\hline Total & 34 & 100,0 \\
\hline \multicolumn{3}{|l|}{ Pengawasan } \\
\hline $\begin{array}{l}\text { Kurang } \\
\text { Baik }\end{array}$ & Baik & 17,6 \\
\hline Baik & 28 & 82,4 \\
\hline Total & 34 & 100,0 \\
\hline \multicolumn{3}{|l|}{$\begin{array}{l}\text { Penggunaan } \\
\text { APD }\end{array}$} \\
\hline Tidak Patuh & 9 & 26,5 \\
\hline Patuh & 25 & 73,5 \\
\hline Total & 34 & 100,0 \\
\hline
\end{tabular}

\section{Analisis Bivariat}

Tabel 2. Hubungan antara variabel bebas dengan Penggunaan APD

\begin{tabular}{llc}
\hline \multicolumn{1}{c}{$\begin{array}{c}\text { Variabel } \\
\text { Bebas }\end{array}$} & \multicolumn{1}{c}{ Kategori } & \multicolumn{1}{c}{$p$} \\
\hline Hubungan & $>35$ tahun & 1,000 \\
Usia & $\leq 35$ tahun & \\
Jenis & Laki-laki & 1,000 \\
Kelamin & Perempuan \\
Masa Kerja & $<5$ tahun \\
& $\begin{array}{l}\geq 5 \text { tahun } \\
\text { Kengetahuan }\end{array}$ & $\begin{array}{l}\text { Kurang } \\
\text { Cukup }\end{array}$ \\
& Baik & 1,000 \\
Pengawasan & Kurang Baik & 0,856 \\
& Baik & 1,000 \\
\hline
\end{tabular}

\section{Pembahasan}

Hasil analisis data diketahui tidak terdapat hubungan antara usia dengan penggunaan APD pada perawat rawat jalan dan rawat inap. Usia merupakan umur individu yang terhitung sejak individu dilahirkan sampai saat ini. Semakin bertambahnya usia seseorang maka semakin menurunnya kemampuan seseorang, seperti kecepatan dalam mengerjakan pekerjaan, kelenturan, kekuatan dan sistem koordinasinya akan ikut mengalami penurunan ${ }^{15}$. Hasil penelitian ini sejalan dengan penelitian di PT X unit 3 \& 4 Kabupaten Jepara. Penelitian tersebut memperoleh hasil bahwa tidak ada hubunan antara usia dengan kepatuhan penggunaan APD dengan p-value sebesar $0,63^{16}$.

Analisis yang dilakukan antara variabel jenis kelamin dengan penggunaan APD diketahui bahwa tidak ada hubungan antara jenis kelamin dengan penggunaan APD pada perawat rawat jalan dan rawat inap. Hal ini terjadi karena lazimnya profesi keperawatan lebih banyak diminati kaum perempuan, mengingat profesi keperawatan lebih dekat dengan masalah-masalah mother instinct, meskipun di era globalisasi atau alasan lain misalnya kesetaraan gender atau juga karena faktor kebutuhan di ruang UGD, OK, dan lain-lain atau mungkin juga karena perkembangan ilmu pengetahuan dan teknologi maka jumlah perawat laki-laki juga mulai dipertimbangkan dan diperhitungkan ${ }^{17}$. Hasil penelitian ini sejalan dengan penelitian di RSUD Banjarbaru. Penelitian tersebut memperoleh hasil bahwa tidak ada hubunan antara jenis kelamin dengan kepatuhan penggunaan APD dengan pvalue sebesar $0,940^{17}$.

Analisis yang dilakukan antara variabel masa kerja dengan penggunaan APD diketahui bahwa tidak ada hubungan antara masa kerja dengan kepatuhan penggunaan APD pada perawat rawat jalan dan rawat inap. Masa kerja yaitu karakteristik individu yang membentuk perilaku sehingga pekerja semakin memahami mengenai kondisi tempat kerja dan memberikan kesadaran untuk patuh dalam pengguaan APD. Masa kerja menjadi faktor yang berhubungan dengan kepatuhan karena semakin lama seseorang bekerja maka kemampuan dan pengalaman dalam bekerja semakin baik. Pekerja dengan masa kerja $>5$ tahun telah memiliki pengalaman yang lebih baik dibandingkan dengan pekerja baru, sehingga lebih paham dengan prosedur aman dalam bekerja ${ }^{18}$. Hasil penelitian ini sejalan dengan penelitian di industri tekstil Kota Semarang. Penelitian tersebut memperoleh hasil bahwa tidak ada hubunan antara masa kerja dengan kepatuhan penggunaan APD dengan p-value sebesar $0,731^{19}$. 
Analisis yang dilakukan antara variabel pengetahuan dengan penggunaan APD diketahui bahwa tidak ada hubungan antara pengetahuan dengan kepatuhan penggunaan APD pada perawat rawat jalan dan rawat inap. Pengetahuan adalah suatu hasil dari dan didapatkan oleh seseorang melalui sistem indera terhadap objek tertentu. Sistem indra terdiri dari 5 panca indra yaitu penglihatan, pendengaran, penciuman, rasa, dan raba. Pengetahuan merupakan salah satu faktor penting dalam mempengaruhi seseorang atau kelompok orang untuk sikap, tindakan, keyakinan, nilai, dan persepsi ${ }^{20}$. Hasil penelitian ini sejalan dengan penelitian di unit produksi alumunium sulfat PT. Liku Telaga Gresik. Penelitian tersebut memperoleh hasil bahwa tidak ada hubunan antara pengetahuan dengan kepatuhan penggunaan APD dengan p-value sebesar $0,483^{21}$.

Analisis yang dilakukan antara variabel pengawasan dengan penggunaan APD diketahui bahwa tidak ada hubungan antara pengawasan dengan penggunaan APD pada perawat rawat jalan dan rawat inap. Kontrol atau pegawasan adalah fungsi di dalam manajemen fungsional yang harus dilaksanakan oleh setiap pimpinan semua unit/satuan kerja terhadap pelaksanaan pekerjaan atau pegawai yang melaksanakan sesuai dengan tugas pokoknya masingmasing. Suatu penyimpangan atau kesalahan terjadi atau tidak selama dalam pelaksanaan pekerjaan tergantung pada tingkat kemampuan dan keterampilan pegawai ${ }^{22}$. Hasil penelitian ini sejalan dengan penelitian di PT Indonesia Power UP Semarang. Penelitian tersebut memperoleh hasil bahwa tidak ada hubunan antara pengawasan dengan kepatuhan penggunaan APD dengan p-value sebesar $0,417^{22}$.

\section{Kesimpulan}

Tidak ada hubungan antara usia dengan kepatuhan penggunaan APD pada perawat di RSU X, $(p=1,000)$. Tidak ada hubungan antara jenis kelamin dengan kepatuhan penggunaan APD pada perawat di RSU X, ( $p$ $=1,000)$. Tidak ada hubungan antara masa kerja dengan kepatuhan penggunaan APD pada perawat di RSU X, ( $p$ $=1,000)$. Tidak ada hubungan antara pengetahuan dengan kepatuhan penggunaan APD pada perawat di RSU X, $(p=0,856)$. Tidak ada hubungan antara pengawasan dengan kepatuhan penggunaan APD pada perawat di RSU X, $(p=1,000)$.

Bagi perawat disarankan untuk patuh menggunakan APD dalam melaksanakan proses kerja serta memanfaatkan fasilitas dan menggunakan Alat Pelindung Diri (APD) yang disediakan oleh rumah sakit yang sesuai dengan jenis bahaya serta kebutuhan yang digunakan dalam masing-masing jenis pekerjaan. Bagi penelitian selanjutnya sebaiknya dilakukan penelitian mengenai hubungan perawat dengan kondisi psikologis pekerja, sehingga dapat diketahui gambaran perbedaan kondisi psikologis perawat berdasarkan tingkat resiko pekerjaan.

\section{Daftar Pustaka}

1. Depkes Ri 2009. Undang-Undang Republik Indonesia Nomor 44 Tahun 2009 Tentang Rumah Sakit. Jakarta [Internet]. 2009;(Rumah Sakit):40. Available From: www.depkes.go.id

2. Organization. Wh. Definisi Rumah Sakit. Who [Internet]. 1947; Available From: Https://www.who.int

3. Permenkes. Peraturan Menteri Kesehatan Republik Indonesia Nomor 340/Menkes/Per/Iii/ 2010 Tentang Klasifikasi Rumah Sakit. Peratur Menteri Kesehat Tentang Rumah Sakit. 2010;340:60.

4. Infodatin-K3. Keselamatan Dan Kesehatan Kerja. 2019. P. 1-8.

5. Tietjen, Linda D. Panduan Pencegahan Infeksi Untuk Fasilitas Layanan Kesehatan Dengan Sumber Daya Terbatas. In: Prawiharjo S, Editor. Yayasan Bina Pustaka; 2004.

6. Cimahi Say. Jurnal Kesehatan Kartika Jurnal Kesehatan Kartika. 2007;35-47.

7. Kusnanto. Profesi Dan Praktik Keperawatan Profesional. Jakarta. Egc; 2003.

8. Nurses. Ic Of. Icn Framework Of Disaster Nursing Competencies. Geneva Switz Int Counc Nurses (Icn). 2009;

9. Pulungsih Sp, Murniati D Ss. Kewaspadaan Universal Di Rumah Sakit Dengan Perhatian Khusus Pada Keselamatan Kerja Petugas Kesehatan. Med J Kedokt. 2003;

10. Aditya Sekti Wibowo, Maria Suryani S. Hubungan Karakteristik Perawat Dengan Penggunaan Sarung Tangan Pada Tindakan Ivasif Di Ruang Rawat Inap Rsud Dr. H. Soewondo Kendal. 2013; Available From: http://journal.umy.ac.id/index.php/mrs/article/vie w/978

11. Geller Es. The Pishcology Of Safety Hanbook. Usa: Lewis Publisher; 2001.

12. Helliyanti P. Faktor-Faktor Yang Berhubungan Dengan Tindakan Tidak Aman Di Departemen Utility Dan Opeartion Pt Indofood Suka Makmur Tahun 2009. 2009;126220.

13. Jasaputra Dk, Santoso S, Editors. Metodologi Penelitian Biomedis Edisi 2. Bandung: 
Danamartha Sejahtera Utama (Dsu); 2008.

14. Prof. Dr. Bhisma Murti. Desain Studi. J Kedokt Sebel Maret. :1-13.

15. Suma'mur Pk. Hiegiene Perusahaan Dan Kesehatan Kerja (Hiperkes). In: Seto S, Editor. Jakarta; 2009.

16. Yard C, Unit Ptx, Tahun Kj, Arifin Ab, Masyarakat Fk. Jurnal Kesehatan Masyarakat 2013 ,. 2013;2.

17. Gladys Apriluana, Laily Khairiyati Rs, Program. Hubungan Antara Usia, Jenis Kelamin, Lama Kerja, Pengetahuan, Sikap Dan Ketersediaan Alat Pelindung Diri (Apd) Dengan Perilaku Penggunaan Apd Pada Tenaga Kesehatan. 2016;3(3):82-7.

18. Kartika Dyah Sertiya Putri Yda. W. Analisis Faktor Yang Berhubungan Dengan Kepatuhan Menggunakan Alat Pelindung Diri. Dep Keselam Dan Kesehat Kerja Fak Kesehat Masy Univ Airlangga. :24-36.
19. Nugroho Ad. Pengaruh Reward Dan Punishment Terhadap Kinerja Karyawan Pt Business. 2015;Iv(2):4-14.

20. S A. Sikap Manusia Teori Dan Pengukurannya. In: Pustaka Pelajar. Jakarta; 2003.

21. Kartika Dyah Sertiya Putri Yda. W. Analisis Faktor Yang Berhubungan Dengan Kepatuhan Menggunakan Alat Pelindung Diri. Dep Keselam Dan Kesehat Kerja Fak Kesehat Masy Univ Airlangga. :24-36.

22. Masyarakat Jk. Faktor Faktor Yang Berhubungan Dengan Kepatuhan Penggunaan Alat Pelindung Diri Pada Pekerja Rekanan (Pt. X) Di Pt Indonesia Power Up Semarang. 2017;5:20-31 